https://www.journal-imab-bg.org

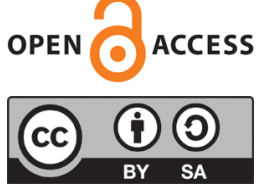

Original article

\title{
IN VITRO EVALUATION OF THE IMPACT OF OPTICAL MAGNIFICATION ON THE PREPARATION FOR VENEERS
}

\author{
Aleksandra Pecheva ${ }^{1}$, Snezhana Tsanova ${ }^{1}$, Ralitsa Raycheva ${ }^{2}$ \\ 1) Department of Operative Dentistry and Endodontics, Faculty of Dental \\ medicine, Medical University of Plovdiv, Bulgaria. \\ 2) Department of Social Medicine and Public Health, Faculty of Public Health, \\ Medical University Plovdiv, Bulgaria..
}

\begin{abstract}
Purpose: The preparation of hard dental tissues for veneers is a very technically demanding process, where minimal invasive manner matters. The optical magnification offers higher resolution; brighter and enlarged threedimensional images which improve the precision and the working posture. The study is evaluating the impact of optical magnification on the precision of tooth preparation under simulated clinical conditions in à digital manner.

Materials and Methods: For the test specimens, 60 plastic upper incisors are divided into 3 groups $(n=20)$ : 1 st group - teeth prepared with a naked human eye.; 2nd group - teeth prepared using compound loups x2,5 magnification; 3rd - teeth prepared using an operating microscope under x6.0 magnification. A laboratory scanning device is used to scan the teeth both before and after the preparation phase. Computer- aided design software is used to overlay the outlines of the teeth it all groups. A sagittal plane is constructed throughout the digital teeth images, and measurements of cut hard dental tissues are done in order to evaluate the accurateness of tooth preparation according to the depth of preparation.

Results: There is a statistical difference between the pre-established volume of preparation and the actual cut of hard dentinal tissues no matter the magnification. There is a statistically significant difference between the depth of preparation in naked eye cases and the magnification cases.

Conclusions: The quantity of cut tissues it more than the preestablished parameters which may affect the quality of the adhesive bond and it is controversy with the minimally invasive approach. The preparation under magnification is much more precise when compared to a naked eye.
\end{abstract}

Keywords: magnification, preparation for veneers, operating microscope, preparation precision,

\section{INTRODUCTION}

The preparation of enamel and dentin in prosthodontics is very technically demanding and especially in dental laminate veneers, where minimal invasive manner matters. Many factors determine the final outcome of the treatment, and one of the most important ones is the quality and accurateness of prepared structures.

Bonded dentistry considers restorative margins as the key to successful restorations with longevity. Margin preparation and outline for a veneer preparation can also be perfected with thorough precision under the scope. [1]

Carr reported that the human eye, when unaided by magnification, has the ability to resolve or distinguish 2 discrete lines or objects separated by a space of $200 \mu \mathrm{m}$ $(0.2 \mathrm{~mm})$. Clinically, most dental practitioners are not able to see an open margin smaller than $0.2 \mathrm{~mm}$. Magnification improves the ability of the eye to resolve these objects and allows the clinician to see greater detail than with the eye alone. For example, 2x magnifiers such as telescopic loupes improve resolution to $100 \mu \mathrm{m}$, and $4 \mathrm{x}$ loupes improve the resolution of the human eye to $50 \mu \mathrm{m}$, or $0.05 \mathrm{~mm}$. [2] In the 20th century, the clinical application of magnificationloupes and operating microscopes is widely spread all over the world.

Compound loupes or telescopic loupes consist of multiple lenses with intervening air spaces, thus allowing adjustment of magnification, working distance, and depth of field without an increase in size or weight [1]. Their magnification range is from $2 \mathrm{x}$ to $8 \mathrm{x}$. Typically, loupes require some form of illumination from an accessory headlamp for adequate visualization of the operating field, especially in cases with a magnification greater than $3.5 x$ [3]. Less expensive and easier to use since they are head mounted, loupes tend to be less cumbersome in the operating field [1]. Leiknius and Geissberger have shown that loupes' magnification, when used by dental students, helped reduce errors in preparation design and laboratory processing by half when compared to a control group not using magnification [4].

There were many steps in the technical development of the operating microscope [5], but nowadays it offers higher resolution and magnification; brighter and enlarged three-dimensional working images, ergonomics posture of the body of the operator $[1,6]$. Working at higher-power magnifications tough brings the clinician into the realm where even slight hand movements are disruptive [7]. 


\section{MATERIALS AND METHODS}

The purpose is to evaluate the impact of optical magnification on the precision of tooth preparation under simulated clinical conditions. The precision of preparation in this study is evaluated according to the depth of preparation. The null hypothesis was that magnification has no influence on the precision of tooth preparation.
For the test specimens, 60 plastic upper incisors are divided into 3 groups $(n=20)$ : 1 st group - teeth prepared with a naked human eye.; 2 nd group - teeth prepared using compound loupes (Rose Micro solution, USA) under $\mathrm{x} 2,5$ magnification; 3rd group - teeth prepared using operating microscope x6.0 magnification (OMS 1950, ZUMAX)

Fig. 1. Veneer preparation on plastic teeth with: A/ naked eye; B/ magnifying loups x2,5; C/ operating microscope $\mathrm{x} 6,0$.
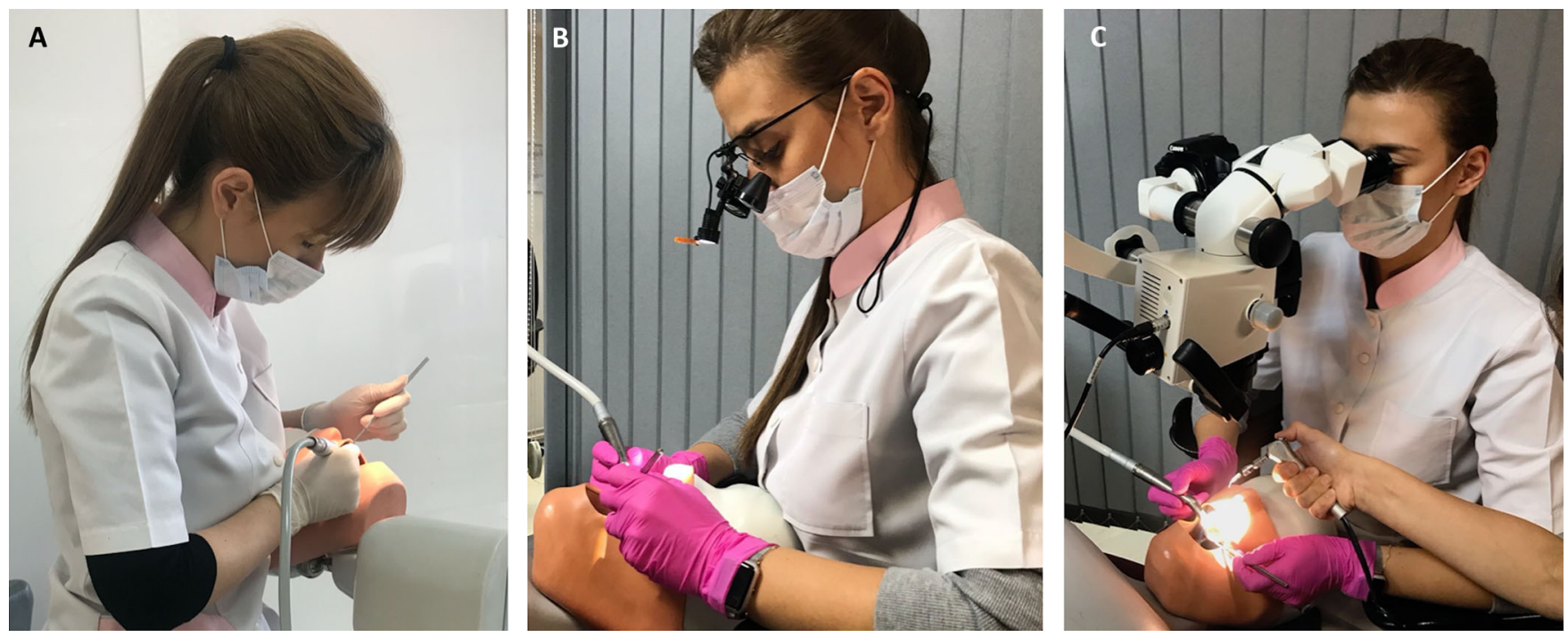

To minimize the influence of technical sensitivities in the fabrication of the prostheses and to standardize their volume and size, one dentist prepared all the specimens, and there was standardization of the preparation design as follow: shoulder marginal finish shape preparation design with incisal reduction; cut of the tissues by $0,3 \mathrm{~mm}$ cervically, by $0,5 \mathrm{~mm}$ at the middle third of the clinical crown and $1,00 \mathrm{~mm}$ incisal reduction.

Three types of turbine burs are used: depth cutter with a depth of preparation $0,3 \mathrm{~mm}$ and $0,5 \mathrm{~mm}$; a cylinder bur with bevelled tip shape and a superfine diamond bur with red coloring (Axis Dental, Switzerland). The preparation begins with marking the depth of preparation in three planes: for the cervical area, a depth-cutter $0,3 \mathrm{~mm}$ positioned parallel to the area; for middle third - depthcutter $0,5 \mathrm{~mm}$ positioned parallelly; for the incisal edge cylindric bur with a rounded tip $\varnothing 1,0 \mathrm{~mm}$, positioned perpendicularly to the edge. The cut fissures are colored with a marker. Using a cylindric bur the buccal wall and the incisal edge are fully prepared up to the chosen depth. The preparation ends with finishing and smoothing the walls with a superfine diamond bur.

Fig. 2. Steps in the preparation for veneer: A/ buccal wall; B/ incisal edge; $\mathrm{C} /$ finished preparation
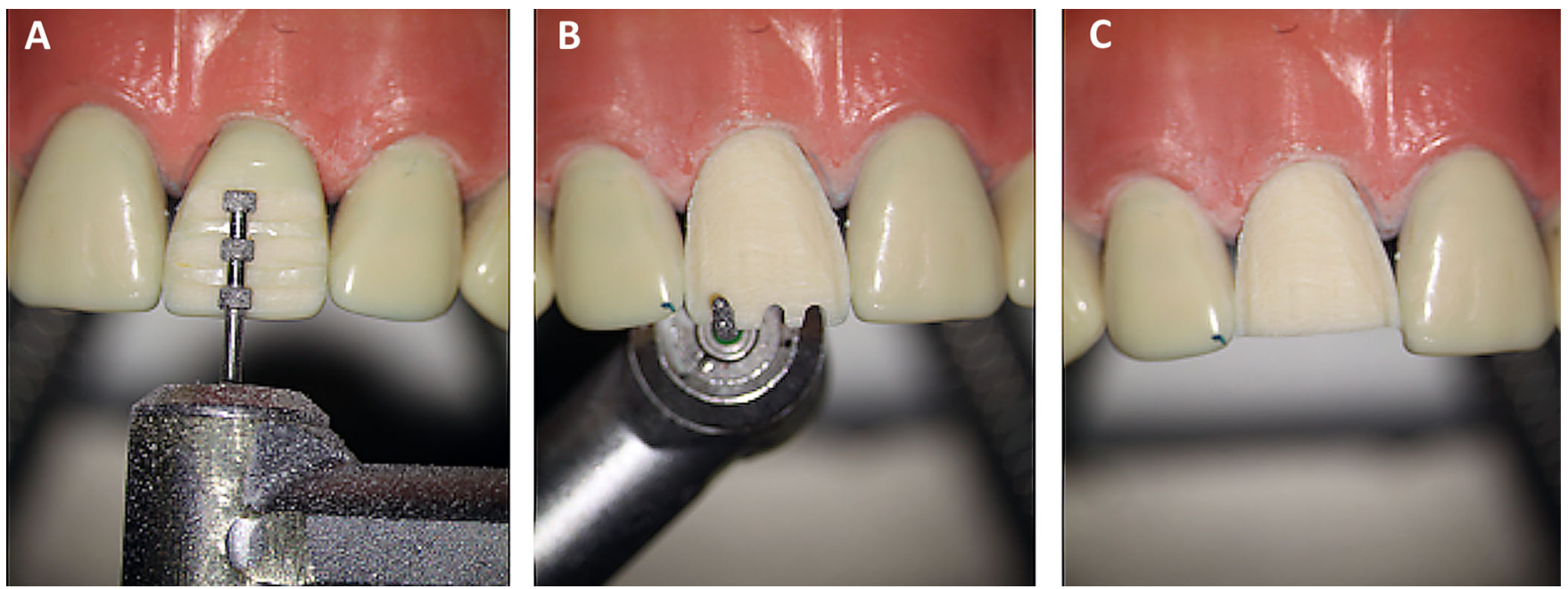
A laboratory scanning device is used to scan the teeth both before. Computer- aided design (CAD 3Shape Trios) software is used to overlay the outlines of the teeth before the preparation with the outlines after the preparation. A sagittal plane is constructed throughout the digital teeth images, and measurements of cut hard dental tissues in cervical, middle and incisal part are performed. These measurements are to evaluate the accurateness of tooth preparation with the following magnification according to the pre-established parameters of the depth of preparation.

Fig. 3. Digital images of an intact tooth) and after the preparation (Wieland D800, Ivoclar Vivadent Group, Germany).
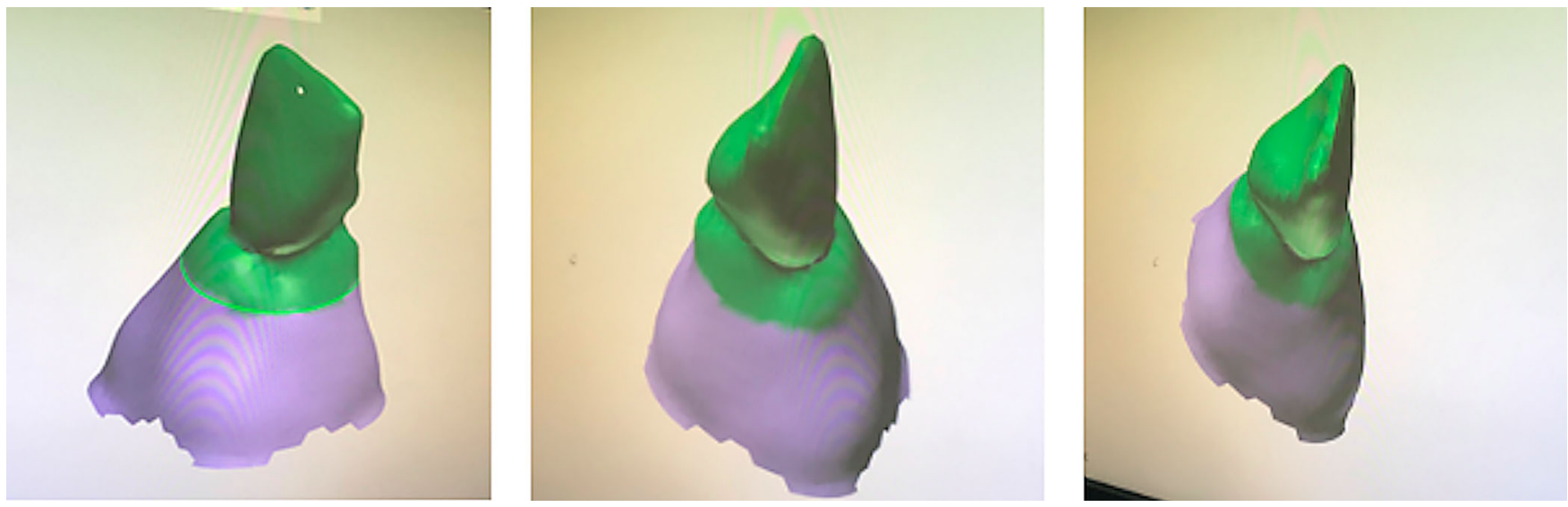

Fig. 4. Measurement of the depth of preparation according to the pre- established parameters: A/ cervical third; $\mathrm{B} /$ middle third; $\mathrm{C} /$ incisal third.
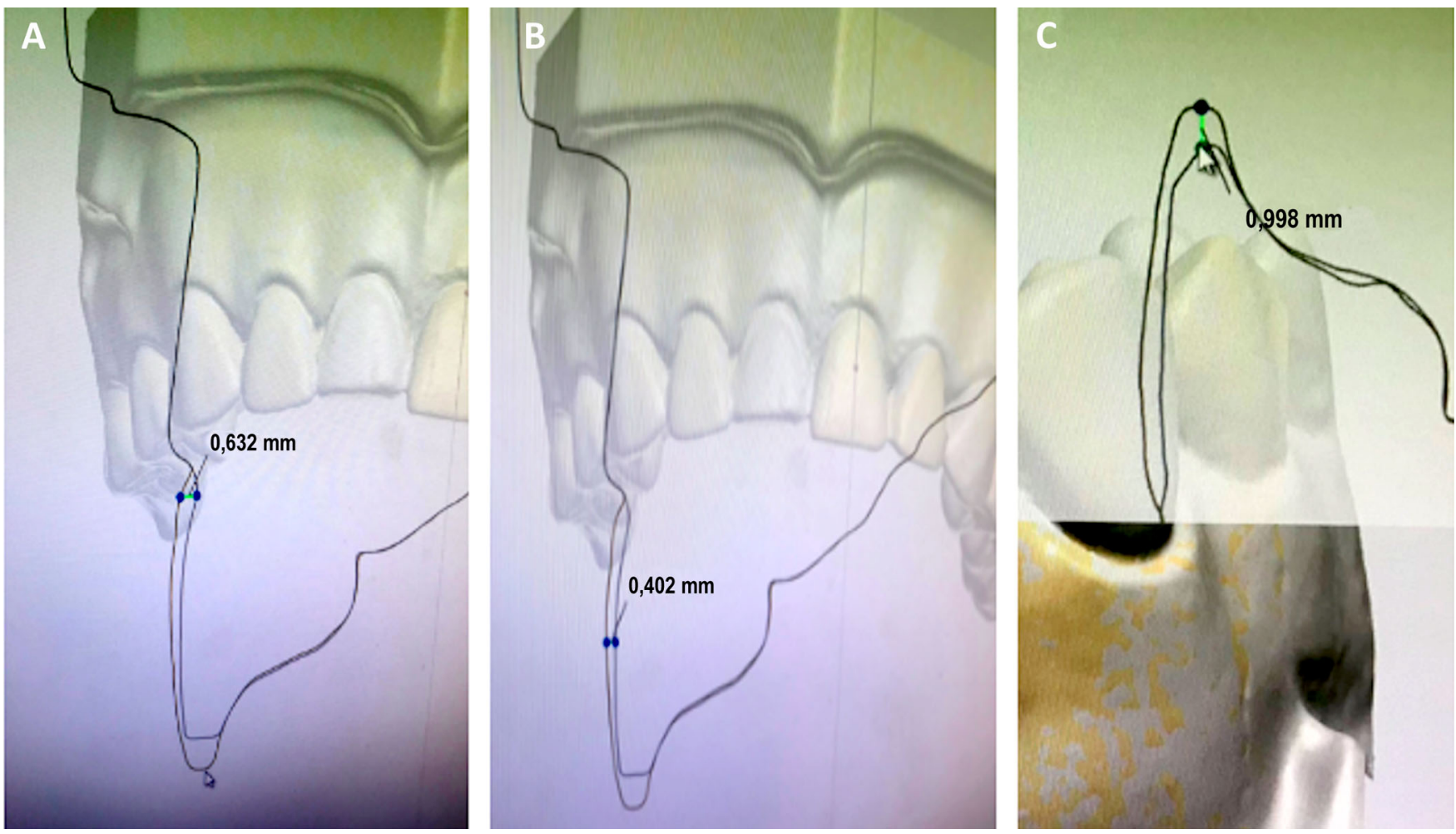

\section{STATISTICAL ANALYSIS}

Descriptive statistics are expressed as mean \pm SE (standard error). Saphiro-Wilk's test is performed to verify departures from basic assumptions about the normality of the data. The comparisons between study groups and baseline depth preparation are performed using one sample ttest. The comparisons between study groups (naked eye vs loupes) are performed using independent sample t-test. Sta- tistical significance is accepted at $\mathrm{p}<0.05$. All statistical computations are made using the IBM SPSS Statistics 22 software package (IBM SPSS Inc., Chicago, IL, USA).

\section{RESULTS}

The descriptive statistics show a depth of preparation for $1 \mathrm{st}$ group- mean values for the cervical third of $0.57 \pm 0.03 \mathrm{~mm}$, for the middle third $0.67 \pm 0.04 \mathrm{~mm}$ and for 
the incisal edge $1.22 \pm 0.04 \mathrm{~mm}$; for 2 nd group - mean values for the cervical third of $0.47 \pm 0.02 \mathrm{~mm}$, for the middle third $0.55 \pm 0.02 \mathrm{~mm}$ and for the incisal edge $1.10 \pm 0.02$ $\mathrm{mm}$; for 3rd group - mean values for the cervical third of $0.48 \pm 0.02 \mathrm{~mm}$, for the middle third $0.54 \pm 0.03 \mathrm{~mm}$ and for the incisal edge $1.12 \pm 0.03 \mathrm{~mm}$.
One sample t-test proved the statistically significant difference between mean values of preparation for all groups and areas versus the baseline depths of preparation $(\mathrm{p}<0,05)$. The only exception is the preparation in the middle third in 3rd group - there is no statistically significant difference between the preestablished $0,5 \mathrm{~mm}$ and the actual depth- 0,54 $\pm 0,03 \mathrm{~mm}$ (table 1).

Table 1. Descriptive statistics.

$\begin{array}{cccc}\text { Mean value } \pm \text { standard error } & \text { Standard } & t & p \\ (\bar{x} \pm S \bar{x}) & \text { deviation } & \end{array}$

1 st group- naked eye

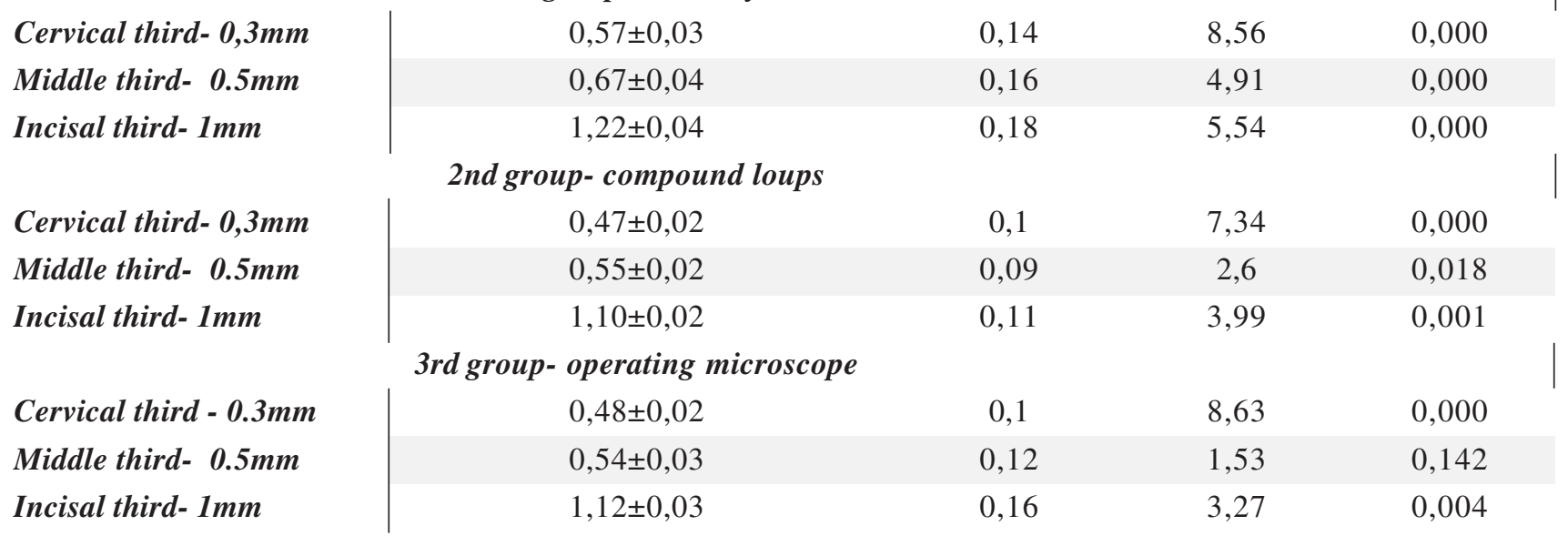

There is statistically significant difference in mean value in incisal third - naked eye $(1.22 \pm 0.04 \mathrm{~mm})$ vs. loupes $(1.11 \pm 0.04 \mathrm{~mm})$ and operating microscope $(1,12 \pm$ $0,03 \mathrm{~mm})$; in middle third - naked eye $(0.67 \pm 0.05 \mathrm{~mm}) \mathrm{vs}$. loupes $(0.53 \pm 0.03 \mathrm{~mm})$ and microscope $(0,54 \pm 0,03)$ and cervical third - naked eye $(0,57 \pm 0,03 \mathrm{~mm})$ vs. loups $(0,47 \pm 0,02 \mathrm{~mm})$ and microscope $(0,48 \pm 0,02 \mathrm{~mm})$.

There is no statistically significant difference in mean values between compound loups and operating microscope.

\section{DISCUSSION}

The statistical analysis shows that the depth of preparation in all examined areas is significantly more extensive than the pre-established parameters. So unneeded cut of dental tissues occurs. An explanation can be found in the technical protocol of preparation - after the depthcuts are done, a smoothening process with a cylindric bur and a finishing bur is performed. This fact is controversial with the contemporary tendency of minimally invasive approach. Most of the scientists insist on minimally invasive preparation in order to establish an excellent adhesive bond between the veneer and the dentinal surface $[8,9]$.

According to Le Sage et al. the successful fixing of veneers relies on the remaining enamel that should be at least $50 \%$ of the whole enamel and at least $50 \%$ of the marginal enamel. Exposure of dentin should be avoided in all the clinical cases it is possible [10].

In a study by Ferrari et al. there is a conclusion that the depth of enamel $1 \mathrm{~mm}$ above the cemento - enamel junction is in a range between $0,17 \mathrm{~mm}$ and $0,52 \mathrm{~mm}$ [11]. According to our measurements, no matter the magnification in almost all of the cases, there will be exposed dentin. It may compromise the strength of the adhesive bond. In the middle and incisal third the quantity of enamel is much more, and dentinal exposure is less likely to occurs when preparing 0,5-0,7 $\mathrm{mm}$.

Statistically, a significant difference is proven between the precision of preparation in the 1 st group and $2 \mathrm{nd} / 3$ rd group. This corresponds with the results of many authors working in the field. An in vitro trial comparing preparation of Class II with loupes and without loupes [12] revealed that cavity preparations are better under magnifying loupes than without loupes, with a statistically significant difference as per kappa values ( 0.64 with loupes and 0.76 without loupes) and Chi-square value (8.01). While evaluating the quality of tooth preparation, around $80 \%$ of the cavity preparations were categorized "satisfactory" with the loupes as compared to $20 \%$, which were categorized "nonsatisfactory". This could be due to the use of magnification that provides greater detail of the oral cavity with better, clearer vision of the operating area, thereby reducing eyestrain, but do so without the need to be closer to the patient.

Similar studies conducted by Buhrley et al., Farook et al., and Maggio et al. showed that working with the magnifications always better. Loupes and microscope not only influence the musculoskeletal health of the professional but also help improve the quality of the treat- 
ment $[13,14]$. The preparation quality improves through the usage of magnifying loupes. The ability to work with a high level of accuracy and improved control reduces treatment time and reduces operator fatigue. Technical knowledge and training are required to ensure that professionals can make the most of the advantages provided by these magnification instruments [15].

\section{CONCLUSION}

Preparation for laminate veneers when magnification is used is much more precise according to depth of preparation of hard dental tissues. Compound loups and operating microscope cause less invasive preparation design. No matter the magnification though, the cut dentinal tissues are more than the preestablished depth of preparation.

\section{REFERENCES:}

1. Hegde R, Hegde V. Magnification-enhanced contemporary dentistry: Getting started. J Interdiscip Dentistry. 2016; 6(2):91-100. [Crossref]

2. Carr GB. Magnification and illumination in endodontics. In: Hardin FJ, editor. Clark's clinical dentistry, 1998; vol. 4. p. 1-14.

3. van As GA. The use of extreme magnification in fixed prosthodontics. Dent Today. 2003 Jun; 22(6):93-9. [PubMed]

4. Leknius C, Geissberger M. The effect of magnification on the performance of fixed prosthodontic procedures. J Calif Dent Assoc. 1995 Dec; 23(12):66-70 [PubMed]

5. Schultheiss D, Denil J. History of the microscope and development of microsurgery: a revolution for reproductive tract surgery. Andrologia. 2002 Sep;34(4):234-41 [PubMed]

6 . Mamoun JS. The maxillary molar endodontic access opening: A microscope-based approach. Eur J Dent. 2016 Jul- Sep;10(3):439-446 [PubMed]
7. Mittal S, Kumar T, Sharma J. An innovative approach in microscopic endodontics. J Conserv Dent. 2014 May;17(3):297-8. [PubMed]

8. LeSage BP. Minimally invasive dentistry: paradigm shifts in preparation design. Pract Proced Aesthet Dent. 2009 Mar-Apr;21(2):97-101. [PubMed]

9. Magne P, Douglas WH. Porcelain veneers: dentin bonding optimization and biomimetic recovery of the crown. Int J Prosthodont. 1999; 12(2):111-21 [PubMed]

10. LeSage B, Wells D. Myths vs. realities: two viewpoints on prepared veneers and prep- less veneers. J Cosm Dent. 2011 Summer;27(2):67-72.

11. Ferrari M, Patroni S, Balleri P. Measurement of enamel thickness in relation to reduction for etched laminate veneers. Int $J$ Periodontics Restorative Dent. 1992; 12(5):407-13 [PubMed]

12. Narula K, Kundabala M, Shetty
N, Shenoy R. Evaluation of Tooth Preparations for Class II Cavities Using Magnification Loupes Among Dental Interns and Final Year BDS Students in Preclinical Laboratory. $J$ Conserv Dent. 2015 Jul-Aug;18(4): 284-7. [PubMed] [Crossref]

13. Farook SA, Stokes RJ, Davis AKJ, Sneddon K, Collyer J. Use of Dental Loupes Among Dental Trainers and Trainees in the UK. J Investig Clin Dent. 2013 May;4(2):120-3. [PubMed]

14. Branson BG, Abnos RM, Simmer-Beck ML, King GW, Siddicky SF. Using Motion Capture Technology to Measure the Effects of Magnification Loupes on Dental Operator Posture: A Pilot Study. Work. 2018; 59(1):131-9. [PubMed]

15. Wajngarten D, Petromilli P. Expanding the Operating Field in Endodontics: From magnification loupes to microscope. Dent oral biology and craniofacial research. 2018 Mar; $1(1): 2-4$

Please cite this article as: Pecheva A, Tsanova S, Raycheva R. In vitro evaluation of the impact of optical magnification on the preparation for veneers. J of IMAB. 2020 Apr-Jun;26(2):3155-3159.

DOI: https://doi.org/10.5272/jimab.2020262.3155

Received: 20/05/2019; Published online: 27/05/2020

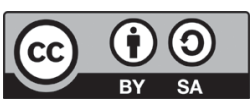

Address for correspondence:

Dr Aleksandra Pecheva,

Department of Operative Dentistry and Endodontics, Faculty of Dental Medicine, Medical University of Plovdiv,

3 Hristo Botev Blvd., Plovdiv 4000, Bulgaria,

E-mail: aleksandra_pecheva@hotmail.com, 